\title{
Measurement of protein $\mathrm{HC}\left(\alpha_{1}\right.$ microglobulin) and protein HC-IgA complex in different body fluids
}

\author{
J L FERNÁNDEZ-LUNA, F LEYVA-COBIÁN, * E MÉNDEZ \\ From Servicio de Endocrinología and *Servicio de Inmunología Centro Ramón y Cajal, Madrid, Spain
}

SUMMARY Protein HC and protein HC-IgA complex were measured in 18 different types of fluid sample from healthy subjects and patients with different illnesses to determine if the concentrations of protein HC and protein HC-IgA complexes could be used to monitor certain diseases, when measured separately. The normal values for $\mathrm{HC}$ ranged from between $0.30 \mathrm{mg} / 1$ in saliva and $11.7 \mathrm{mg} / \mathrm{l}$ in blood plasma. HC-IgA complex has a greater range, from undetectable concentrations (urine, colostrum, and cervical mucus) up to $59.2 \mathrm{mg} / \mathrm{l}$ in blood plasma. Undetectable concentrations of HC-IgA complex were also shown in serum from patients with IgA immune deficiency and in cerebrospinal fluid from patients with multiple sclerosis. Increased concentrations of $\mathrm{HC}$ were noted in bronchoalveolar fluid from a patient with pulmonary alveolar proteinosis, serum from patients with Behcet's syndrome, and in synovial fluid from patients with gout, chondrocalcinosis, and rheumatoid arthritis. On the other hand, the concentrations of HC-IgA complex were raised only in those patients with pulmonary alveolar proteinosis or rheumatoid arthritis.

Human complex forming glycoprotein heterogeneous in charge (protein $\mathrm{HC}$ ), also called $\alpha_{1}$-microglobulin, is a low molecular weight glycoprotein originally isolated from normal urine samples. ${ }^{1}$ The protein is widely distributed in body fluids as free form and complexed with $\operatorname{IgA}(\mathrm{HC}-\operatorname{IgA}) .^{12}$ The free protein displays considerable charge heterogeneity ${ }^{1}$ and carries an unidentified yellow-brown chromophore which does not correspond to any previously described human chromophore, ${ }^{3}$ but no chromophore was found to be associated with the IgA complexed with protein $\mathrm{HC}{ }^{4}$

Both HC and HC-IgA complex have been shown to inhibit neutrophil chemotaxis against endotoxin activated serum in in vitro assays, suggesting that protein HC may have a physiological role in the regulation of inflammatory response. ${ }^{5}$ It has recently been reported that HC-IgA complex carries antibody activity and that it comprises three types of chains: two light immunoglobulin chains, one regular $\operatorname{IgA} \alpha$-chain, and one chain carrying both $\alpha$-chain and protein HC epitopes. ${ }^{6}$

Since the characterisation of protein $\mathrm{HC} 10$ years ago, all the immunotechniques used to quantify the concentrations of protein $\mathrm{HC}$ in body fluids have allowed only total protein HC (free HC and HC-IgA complex) to be measured. ${ }^{7-15}$

Accepted for publication 2 June 1988
We reported the use of a crossed immunoelectro- $\cap$ phoresis method, ${ }^{2}$ and more recently a combined competitive and sandwich enzyme immunoassay for the simultaneous quantitation of $\mathrm{HC}$ and $\mathrm{HC}-\operatorname{IgA}=$ complex. ${ }^{16}$ This paper reports the concentration of free $\mathrm{HC}$ and $\mathrm{HC}$-IgA complex in 18 different human body fluids from healthy subjects and patients with different illnesses.

\section{Material and methods}

Eight different body fluids from healthy adults and 10 body fluids from patients with different illnesses were analysed. A detailed description of the patients is given in table 1.

Blood was collected from registered donors by venepuncture in sterile tubes. Plasma was obtained in the presence of sodium heparinate $(14 \mathrm{IU} / \mathrm{ml})$ by centrifugation at $1500 \times g$ for 10 minutes at room temperature.

Human colostrum was collected from healthy women just after having given birth. The samples were centrifuged for 30 minutes at $5000 \times g$ to remove fat and cellular pellet. The colostrum was then immediately frozen until required.

Synovial fluid was collected at the time of a clinically indicated diagnostic arthrocentesis. All samples were obtained aseptically from the knee in heparinised tubes and treated with hyaluronidase $(5 \mathrm{IU} / \mathrm{ml})$ for 15 
Table 1 Clinical characteristics of patients studied

\begin{tabular}{|c|c|c|c|c|}
\hline Diagnosis & No of patients & Age range (years) & $\operatorname{Sex}(F / M)$ & Treatment and clinical state \\
\hline Selective IgA deficiency & 6 & $11-26$ & $4 / 2$ & $\begin{array}{l}\text { None, four patients with recurrent } \\
\text { upper respiratory infections }\end{array}$ \\
\hline $\begin{array}{l}\text { Behcet's disease } \\
\text { Multiple sclerosis } \\
\text { Liver cirrhosis } \\
\text { Pulmonary alveolar proteinosis } \\
\text { Degenerative joint disease } \\
\text { Acute gouty arthritis } \\
\text { Rheumatoid arthritis } \\
\text { Chondrocalcinosis }\end{array}$ & $\begin{array}{l}7 \\
4 \\
4 \\
1 \\
6 \\
5 \\
8 \\
4\end{array}$ & $\begin{array}{l}27-49 \\
29-51 \\
49-62 \\
15 \\
58-84 \\
44-68 \\
40-61 \\
60-67\end{array}$ & $\begin{array}{l}6 / 1 \\
3 / 1 \\
0 / 4 \\
1 / 0 \\
3 / 3 \\
0 / 5 \\
5 / 3 \\
2 / 2\end{array}$ & $\begin{array}{l}\text { None; active disease } \\
\text { None; relapsing-remitting disease } \\
\text { Non-steroidal drugs } \\
\text { Antibiotics } \\
\text { None } \\
\text { Two patients were taking colchicine } \\
\text { Non-steroid drugs } \\
\text { None }\end{array}$ \\
\hline
\end{tabular}

minutes at $37^{\circ} \mathrm{C}$ to reduce viscosity. Finally, samples were centrifuged at $1500 \times g$ for 15 minutes at $4^{\circ} \mathrm{C}$ and the supernatant collected. To avoid the possibility of peripheral blood contamination, blood stained specimens were excluded.

Control synovial fluids were collected from four patients with traumatic synovitis during meniscectomy.

Cerebrospinal fluid (CSF) was obtained by lumbar puncture as a part of clinical diagnostic procedures.

Bronchoalveolar fluid was obtained from bronchoalveolar washing performed by transnasal fibreoptic bronchoscopy in a patient with pulmonary alveolar proteinosis (PAP) and in an age matched control. The recovery of instilled fluid was $62 \%$ in the patient with PAP and $50 \%$ in the control. HC and HCIgA complex concentrations are given in relation to volume of bronchoalveolar fluid recovered.

Saliva, seminal fluid, and cervical mucus samples were obtained from normal subjects and used without any further treatment.

\section{ENZYME IMMUNOASSAY}

Quantitation of HC and HC-IgA complex was carried out using a sensitive enzyme linked immunosorbent assay (ELISA) recently described. ${ }^{16}$ Briefly, the total amount of HC (free plus IgA-complexed) was measured by a competitive procedure while the HCIgA complex was quantitated by a sandwich enzyme immunoassay. The amount of free $\mathrm{HC}$ was then obtained as the difference between the two measured values. The sensitivity of the immunoassay was $0.07 \mathrm{mg} / \mathrm{l}$ for the total amount of $\mathrm{HC}$ and $0.08 \mathrm{mg} / \mathrm{l}$ for the HC-IgA complex. Both enzyme immunoassays were used to identify $\mathrm{HC}$ and $\mathrm{HC}$-IgA complex during their isolation.

\section{Results}

The concentrations of $\mathrm{HC}$ and $\mathrm{HC}$-IgA complex in body fluids from healthy subjects are shown in table 2 . The concentration ratio between these two molecular species of HC showed great differences, depending on the sample tested. In blood plasma the mean concentration of HC and HC-IgA complex were 11.7 and $59.2 \mathrm{mg} / 1$ (ratio 1:5), respectively. These results were not significantly different from those obtained in serum samples. On the other hand, the mean concentrations obtained in saliva $(0.30 \mathrm{mg} / 1$ of $\mathrm{HC}$ and $0.16 \mathrm{mg} / 1$ of HC-IgA complex), seminal plasma (5.20 mg/l of HC and $0.92 \mathrm{mg} / 1$ of HC-IgA complex), and bronchoalveolar fluid $(0.55 \mathrm{mg} / \mathrm{l}$ of $\mathrm{HC}$ and $0.091 \mathrm{mg} / 1$ of HC-IgA complex) corresponded to HC:HC-IgA concentration ratios of $2: 1,6: 1$, and $6: 1$, respectively. In the samples of urine, colostrum, and cervical mucus, the concentrations of $\mathrm{HC}-\mathrm{IgA}$ complex were undetected by the sandwich ELISA, and the mean values of $\mathrm{HC}$ were $3.87,2.27$, and $0.76 \mathrm{mg} / 1$, respectively.

Samples from patients with different illnesses were also studied (table 3). Sera from patients with IgA immune deficiency presented a mean value of

Table 2 Protein HC and protein HC-IgA complex concentrations in normal body fluids

\begin{tabular}{|c|c|c|c|c|c|c|c|}
\hline \multirow[b]{2}{*}{ Sample } & \multirow[b]{2}{*}{$(n=)$} & \multicolumn{3}{|c|}{ Protein HC (mg/l) } & \multicolumn{3}{|c|}{$H C-I g A$ complex (mg/l) } \\
\hline & & Mean & $S D$ & Range & Mean & $S D$ & Range \\
\hline $\begin{array}{l}\text { Blood plasma } \\
\text { Serum } \\
\text { Urine } \\
\text { Colostrum } \\
\text { Saliva } \\
\text { Seminal fluid } \\
\text { Cervical mucus } \\
\text { Bronchoalveolar fiuid }\end{array}$ & $\begin{array}{r}10 \\
20 \\
20 \\
4 \\
4 \\
4 \\
1 \\
1\end{array}$ & $\begin{array}{l}11 \cdot 7 \\
9 \cdot 60 \\
3 \cdot 87 \\
2 \cdot 27 \\
0 \cdot 30 \\
5 \cdot 20 \\
0 \cdot 76 \\
0 \cdot 55\end{array}$ & $\begin{array}{l}5 \cdot 96 \\
3 \cdot 40 \\
1 \cdot 48 \\
0 \cdot 81 \\
0.07 \\
1 \cdot 28\end{array}$ & $\begin{array}{l}4 \cdot 13-25 \cdot 4 \\
4 \cdot 80-21 \cdot 4 \\
2 \cdot 14-6 \cdot 28 \\
1 \cdot 46-3 \cdot 59 \\
0.23-0.37 \\
3 \cdot 07-6.53\end{array}$ & $\begin{array}{r}59.2 \\
52.4 \\
<0.08 \\
<0.08 \\
0.16 \\
0.92 \\
<0.08 \\
0.091\end{array}$ & $\begin{array}{l}25 \cdot 7 \\
35 \cdot 8\end{array}$ & $\begin{array}{l}21 \cdot 9-95 \cdot 6 \\
25 \cdot 3-118\end{array}$ \\
\hline
\end{tabular}


Table 3 Protein HC and protein HC-IgA complex concentrations in body fluids from patients with different illnesses

\begin{tabular}{|c|c|c|c|c|c|c|c|c|}
\hline \multirow[b]{2}{*}{ Diagnosis } & \multirow[b]{2}{*}{ Sample } & \multirow[b]{2}{*}{$(n=)$} & \multicolumn{3}{|c|}{ Protein $H C$ (mg/l) } & \multicolumn{3}{|c|}{ HC-IgA complex (mg/l) } \\
\hline & & & Mean & $S D$ & Range & Mean & $S D$ & Range \\
\hline $\begin{array}{l}\text { IgA immunodeficiency } \\
\text { Behcet's syndrome } \\
\text { Multiple sclerosis } \\
\text { Liver cirrhosis } \\
\text { Pulmonary alveolar } \\
\text { proteinosis }\end{array}$ & $\begin{array}{l}\text { Serum } \\
\text { Serum } \\
\text { Cerebrospinal fluid } \\
\text { Ascitic fluid } \\
\text { Bronchoalveolar } \\
\quad \text { fluid }\end{array}$ & $\begin{array}{l}6 \\
7 \\
4 \\
4 \\
1\end{array}$ & $\begin{array}{c}7.58 \\
26.9 * \\
0.095 \\
3.01 \\
27 \cdot 2\end{array}$ & $\begin{array}{l}1 \cdot 83 \\
10 \cdot 3 \\
0 \cdot 019 \\
1 \cdot 22\end{array}$ & $\begin{array}{c}5.49-9.95 \\
13.9-38.6 \\
0.074-0.133 \\
1.53-4.93\end{array}$ & $\begin{array}{c}<0.08 \\
13.6 \dagger \\
<0.08 \\
4.70 \\
0.55\end{array}$ & $\begin{array}{l}5 \cdot 28 \\
3 \cdot 63\end{array}$ & $\begin{array}{l}11 \cdot 5-23 \cdot 0 \\
1 \cdot 20-9 \cdot 60\end{array}$ \\
\hline
\end{tabular}

p $<0.001 ;$ tp < 0.01. Statistical significance calculated in relation with normal values in table 2 .

$7.58 \mathrm{mg} / \mathrm{l}$ of $\mathrm{HC}$ and undetectable concentrations of HC-IgA complex. The mean concentration of $\mathrm{HC}$ in sera from patients with Behcet's syndrome was $26.9 \mathrm{mg} / \mathrm{l}$, three times higher than the normal value, while the mean concentration of HC-IgA complex was $13.6 \mathrm{mg} / \mathrm{l}$, four times less than the normal value. The HC:HC-IgA concentration ratio (2:1) was therefore inverted in these patients.

Cerebrospinal fluid from patients with multiple sclerosis presented undetectable concentrations of HC-IgA complex and very low concentrations of HC $(0.095 \mathrm{mg} / \mathrm{l})$. Ascitic fluid from patients with alcoholic liver cirrhosis showed a mean value of $3.01 \mathrm{mg} / \mathrm{l}$ of $\mathrm{HC}$ and $4.70 \mathrm{mg} / \mathrm{l}$ of $\mathrm{HC}$-IgA complex.

The most striking increase in both proteins was observed in bronchoalveolar fluid from a patient with PAP $-27.2 \mathrm{mg} / 1$ of $\mathrm{HC}$ and $0.55 \mathrm{mg} / 1$ of $\mathrm{HC}-\mathrm{IgA}$ complex, with a concentration ratio of 49:1.

The concentrations of both HC and HC-IgA complex in synovial fluid from patients with inflammatory and non-inflammatory joint diseases were also studied (table 4). Those with traumatic synovitis showed a mean value of $6.90 \mathrm{mg} / \mathrm{l}$ of $\mathrm{HC}$ and $6.24 \mathrm{mg} / \mathrm{l}$ of $\mathrm{HC}$ IgA complex (ratio 1:1). These concentrations were taken as normal reference values for synovial fluid. We also analysed the synovial fluid from patients with degenerative joint disease-values of $9.20 \mathrm{mg} / \mathrm{l}$ of HC and $5.82 \mathrm{mg} / \mathrm{l}$ of HC-IgA complex, with a concentration ratio of $2: 1$.

Of the inflammatory joint diseases studied, patients with gout and chondrocalcinosis showed an HC:HC-IgA concentration ratio of $3: 1$, while in the patients with rheumatoid arthritis this ratio was inverted (1:1-8). In all cases the mean value of $\mathrm{HC}$ was between two and three times higher than that in non-inflammatory processes.

\section{Discussion}

The concentrations of protein $\mathrm{HC}$ and protein $\mathrm{HC}$ IgA complex in body fluids from healthy subjects and patients with clinical disorders were measured by using a combined competitive and sandwich ELISA. ${ }^{16}$ Of normal samples of blood plasma and serum, the mean values of HC-IgA complex were higher than those of $\mathrm{HC}$, reaching an $\mathrm{HC}: \mathrm{HC}-\mathrm{IgA}$ concentration ratio of $1: 5$, in other normal body fluids the concentra- tions of HC-IgA complex were much lower (saliva, seminal fluid, and bronchoalveolar fluid) or undetectable (urine, colostrum, and cervical mucus) (table 2).

Interestingly, HC-IgA complex was not detected in samples rich in IgA concentrations which was surprising. In the case of urine, undetectable HC-IgA complex may have been attributable to the selective exclusion of large molecules due to the renal filter, but we could find no explanation for our inability to detect HC-IgA complex in the other samples.

An interesting difference between the concentrations of the two proteins was observed in the group of patients with Behcet's syndrome. It is known that these patients have, among other abnormalities, increased neutrophil and monocytic chemotactic activity. Hypothetically, an increased chemotactic response could be due to a depletion in the concentrations of chemotaxis inhibitors. We recently reported that protein $\mathrm{HC}$ and its $\operatorname{IgA}$ complex inhibits in vitro the normal neutrophil chemotaxis. ${ }^{5}$ The results showed that concentrations of $\mathrm{HC}$ tended to be high in patients with Behcet's syndrome (mean of $26.9 \mathrm{mg} / \mathrm{l}$ ) in contrast to those of HC-IgA complex (mean of $13.6 \mathrm{mg} / \mathrm{l})$. The reason for this discrepancy is unclear, and a greater understanding of the function of $\mathrm{HC}$ may be necessary.

On the other hand, we did not detect the presence of HC-IgA complex in the CSF from patients with multiple sclerosis. The most striking increase in $\mathrm{HC}$ was found in bronchoalveolar fluid from a patient with PAP (table 3) as there is an accumulation of phospholipids, immunoglobulins, and other serum proteins in the alveoli and distal airways of the lungs. ${ }^{17}$ The HC:HC-IgA concentration ratio in this patient was 49:1, very different from that of other body fluids.

The concentrations of $\mathrm{HC}$ and HC-IgA complex were also measured in synovial fluid from patients with inflammatory and non-inflammatory joint diseases (table 4).

Because the self-amplifying character of the inflammatory response seems to be mediated in part through chemotactic factors, it has been suggested that a chemotactic inhibitor might serve as a component of a postulated regulatory mechanism. ${ }^{18}$ The results showed that protein HC concentrations in patients with gout and chondrocalcinosis were the most 
Table 4 Protein HC and protein HC-IgA complex concentrations in synovial fluid from patients with joint disease

\begin{tabular}{|c|c|c|c|c|c|c|c|}
\hline \multirow[b]{2}{*}{ Diagnosis } & \multirow[b]{2}{*}{$(n=)$} & \multicolumn{3}{|c|}{ Protein HC (mg/l) } & \multicolumn{3}{|c|}{ HC-IgA complex (mg/l) } \\
\hline & & Mean & $S D$ & Range & Mean & $S D$ & Range \\
\hline $\begin{array}{l}\text { Traumatic synovitis } \\
\text { Degenerative joint disease } \\
\text { Acute gouty arthritis } \\
\text { Rheumatoid arthritis } \\
\text { Chondrocalcinosis }\end{array}$ & $\begin{array}{l}4 \\
6 \\
5 \\
8 \\
4\end{array}$ & $\begin{array}{l}6 \cdot 90 \\
9 \cdot 20 \\
14 \cdot 7^{*} \\
10 \cdot 8 \\
19 \cdot 2^{*}\end{array}$ & $\begin{array}{l}1.46 \\
2.05 \\
4 \cdot 14 \\
9 \cdot 50 \\
6 \cdot 75\end{array}$ & $\begin{array}{c}5 \cdot 44-8 \cdot 37 \\
5 \cdot 70-12 \cdot 1 \\
9 \cdot 09-19 \cdot 3 \\
4 \cdot 56-30 \cdot 0 \\
10 \cdot 5-28 \cdot 0\end{array}$ & $\begin{array}{r}6 \cdot 24 \\
5 \cdot 82 \\
4 \cdot 79 \\
19 \cdot 9^{*} \\
5.92\end{array}$ & $\begin{array}{l}1.44 \\
3.08 \\
2 \cdot 18 \\
8 \cdot 80 \\
0.80\end{array}$ & $\begin{array}{l}4 \cdot 80-7.68 \\
1 \cdot 44-9.60 \\
2 \cdot 88-8.96 \\
8 \cdot 32-33 \cdot 2 \\
4 \cdot 80-7.04\end{array}$ \\
\hline
\end{tabular}

* $p<0.01$. Statistical significance calculated in relation to values for traumatic synovitis.

increased (about two to three times higher than those of non-inflammatory processes, traumatic synovitis, and degenerative joint disease). On the other hand, protein HC-IgA complex concentrations were almost invariant, between 4.79 and $6.24 \mathrm{mg} / \mathrm{l}$, except in rheumatoid arthritis where the HC-IgA complex concentration reached up to 19.9 (SD 8.8$) \mathrm{mg} / \mathrm{l}$. Interestingly, about half the patients with a chronic form of rheumatoid arthritis have serum IgA above the normal range and some of the serum IgA is complexed covalently to $\alpha$-globulins. ${ }^{19}$ Measurement of the concentrations of $\mathrm{HC}$ and $\mathrm{HC}$-IgA complex in synovial fluids may therefore be a useful tool for discriminating between joint disorders.

In accordance with the findings of this study, the fluids can be grouped into four different categories. In the first, both components are present in high amounts, but the concentration of HC-IgA complex is two to five times higher than that of free HC (normal blood plasma and serum, ascitic fluid from patients with liver cirrhosis, and in synovial fluids of patients with rheumatoid arthritis). The second group also has a high concentration, but the concentration of free $\mathrm{HC}$ is higher than HC-IgA complex (serum of patients with Behcet's syndrome, synovial fluids from those with chondrocalcinosis, acute gouty arthritis, traumatic synovitis, and degenerative joint disease, and bronchoalveolar fluid from a patient with pulmonary alveolar proteinosis and normal seminal fluid). In the third, both components are present at a very low concentration, but free $\mathrm{HC}$ is also higher than HC-IgA complex (cerebrospinal fluid from patients with multiple sclerosis and saliva from a control). In the fourth group free HC only is present (normal urine, normal colostrum, normal cervical mucus and sera from patients with IgA immune deficiency).

We are grateful to Dr A O Grubb, department of clinical chemistry, University of Lund, Sweden, for supplying protein $\mathrm{HC}$ and $\mathrm{HC}$-IgA complex and the monoclonal antibody against protein HC. This work was supported by grants from the Comision Asesora para Desarrollo de la Investigación Científica y Técnica y Fondo de Investigaciones Sanitarias de la Seguridad Social.

\section{References}

1 Tejler L, Grubb AD. A complex-forming glycoprotein heterogeneous in charge and present in human plasma, urine and cerebrospinal fluid. Bichem Biophys Acta 1976;439:82-94.

2 Grubb AO, Lopez C, Tejler L, Méndez E. Isolation of human complex-forming glycoprotein, heterogeneous in charge (protein HC) and its IgA complex from plasma. $J$ Biol Chem 1983;258:14698-707.

3 Gavilanes J, Lopez C, Gavilanes F, Méndez E. Confirmational studies of the human complex-forming glycoprotein heterogeneous in charge: protein HC. Biochemistry 1984;23:1234-8.

4 Escribano J, Matas R, Méndez E. HPLC and photodiode array detection of human protein HC: a chromophore associated protein. J Chromatography 1988;444:165-75.

5 Méndez E, Fernández-Luna JL, Grubb AD, Leyva-Cobian F. Human protein HC and its IgA complex are inhibitors of neutrophil chemotaxis. Proc Natl Acad Sci USA 1986;83: 1472-5.

6 Grubb AO, Méndez E, Fernández-Luna JL, Lopez C, Mihaesco E, Vaerman J-P. The molecular organisation of the protein HCIgA complex (HC-IgA). J Biol Chem 1986;261:14313-20.

7 Takagi K, Itoh Y, Enomoto H, Koyamaishi Y, Maeda K, Kawai T. A comparative study of serum $\alpha_{1}$-microglobulin and $\beta_{2}$ microglobulin levels in cancerous and other diseases. Clin Chim Acta 1980;108:277-83.

8 Bernier I, Dautigny A, Jolles P. Characterization of $\alpha_{1}$ microglobulin in human colostrum and milk. Experimentia 1980;36:1419.

9 Itoh Y. Diurnal variation of serum $\alpha_{1}$-microglobulin in normal subjects. Nephron 1981;29:204.

10 Takagi K, Kin K, Itoh Y, Enomoto H, Kawai T. Human $\alpha_{1}-$ microglobulin levels in various body fluids. J Clin Pathol 1980;33:786-91.

11 Ekstrom B, Berggard I. Human $\alpha_{1}$-microglobulin. Purification procedure, chemical and physiochemical properties. $J$ Biol Chem 1977;252:8048-57.

12 Svensson L, Ravnskov U. $\alpha_{1}$-microglobulin. A new low molecular weight plasma protein. Clin Chim Acta 1976;76:415-22.

13 Itoh Y, Nishino H, Enomoto H, Kawai T. A double antibody radioimmunoassay for human $\alpha_{1}$-microglobulin. Clin Chim Acta 1986;155:221-6.

14 Itoh Y, Enomoto H, Takagi K, Obayashi T, Kawai T. Human $\alpha_{1}$ microglobulin levels in neurological disorders. Eur Neurol 1983;22:1-6.

15 Kawai T, Takagi K. Sandwich enzyme immunoassay of $\alpha_{1-}$ microglobulin. In: Ishikawa E, Kawai T, Miyai K, eds. Enzyme immunoassay. Tokyo: Igaku-Shoin, 1981:217-24.

16 Fernández-Luna JL, Moneo I, Grubb AO, Méndez E. A sensitive and rapid enzyme-linked immunosorbent assay using monoclonal antibodies for simultaneous quantitation of free and IgAcomplexed protein HC. J Immunol Methods 1985;82:101-10.

17 Claypool WD, Rogers RM, Matuschak GM. Update on the clinical diagnosis, management and pathogenesis of pulmonary alveolar proteinosis (phospholipidosis). Chest 1984;85:550-8.

18 Matzner Y, Partridge REH, Babior BM. A chemotactic inhibitor in synovial fluid. Immunology 1983;49:131-8.

19 Stanworth DR. IgA dysfunction in rheumathoid arthritis. Immunology Today 1985;6:43-5.

Requests for reprints to: Dr E Méndez, Servicio de Endocrinologia, Centro Ramón y Cajal, Carretera de Colmenar, Km 9, 100, 28034 Madrid, Spain. 